\title{
The welfare courts: A socio-legal analysis of risk management through modern strict liability
}

\author{
Domenico Tosini* \\ Department of Sociology and Social Research, University of Trento, Facoltà di Sociologia, \\ Via Verdi 26-38100 Trento, Italy
}

\begin{abstract}
The aim of the essay is to offer an adequate theoretical framework for a socio-legal analysis of risk management by the legal system. Law and risk are the two most important concepts to be clarified. Unlike the law, whose function consists in the temporal stabilisation of normative expectations, the perspective of risk is characterised by the possibility of changing the criteria for decisions based upon the evaluation of the consequences of those decisions. In the context of a modern society, characterised by an increasing demand for protection for people injured by new technologies, one observes certain difficulties in the attempt to adopt a risk perspective within the legal system. The result of this process is the new law of tort based upon the modern principles of strict liability. While strict liability can be shown to be effective in managing conflicts relating to technological accidents, its most negative effects are the increasing instability of legal structures and interference with the activities of other subsystems of society, such as medicine and the economy.
\end{abstract}

(C) 2006 Elsevier Ltd. All rights reserved.

Keywords: Stabilisation of normative expectations; Risk; Risk communication; Ecological communication; Legal ecological communication; Economic and personal loss; Fault; Strict liability

\section{Introduction}

The fundamental purpose of the following essay is to present the outline of a sociological analysis of risk management through the legal instrument known as strict liability. In the last 20 years, many essays have paid attention to the issue of risk and

*Tel.: + 393472329219 ; fax: + 390461881348 .

E-mail address: domenico.tosini@soc.unitn.it. 
numerous researchers have focused on the topic of risk and legal intervention. Nevertheless, such analyses have failed to offer a satisfactory framework and conceptual background for an understanding of the nature of risk and the corresponding legal solutions to it.

The clearest reason for such a deficiency lies, first of all, in the lack of a precise concept of risk and law. We shall try to present these concepts in Section 2. Subsequently, after a short assessment of the legal principles supporting strict liability, in Section 3, we shall propose a socio-legal analysis, in Section 4, whose main thesis is that strict liability has to be understood as a social mechanism for dealing with a specific problem of contemporary society, namely that of compatibility between dangerous, but useful social activities, on the one hand, and the increasing attention paid to the integrity of human beings and the environment, on the other. If strict liability is applied correctly to address such problems, however, it triggers off its own negative consequences in the form of a contradiction within the law, in that its legal structure is manifestly in conflict with the function of the law itself, as currently assumed by our theoretical premises.

\section{Law and risk}

The first step of our analysis is the concept of law. For this purpose, we shall assume the perspective of systems theory. According to this theory, society can be defined as a system consisting of communications (Luhmann, 1995a). Communication is the specific basis on which society operates. It is a process of exchange between at least two individuals, in which a message (utterance) of ego (psychic system 1) is observed (understood) by alter (psychic system 2) attributing to ego such a message and associating it with a meaning (information). Communication is a reciprocal exchange between ego and alter, excluding any interconnection of their bodies or consciousnesses. All that is not communication can then be identified as the environment of society. From this point of view, human beings, as well as the natural environment (biosphere), do not belong to society. This is documented by the empirical proof that human beings are composed of two specific systems whose elements are not communication: the first a biological system reproducing a physical-chemical synthesis (proteins); the other a nervous system or consciousness elaborating its own operation known as synaptic transmissions (which we can more simply denominate as thoughts). In sum, the extra-communicative nature of the biological and nervous systems clarifies their own conceptual and empirical placing in the environment of society.

The reproduction of society requires a solution to specific problems. The social task of law is to deal with a particular problem, which we can identify as the stabilisation of normative expectations. This term involves a fundamental requirement of everyday life: the need to know in advance, in as precise a way as possible, the valid norms of social life, so that decisions can be made with the prior knowledge of whether or not our own behaviour will be approved of or punished. Legal procedures and legal decisions are in modern and contemporary everyday life the fundamental processes used to fix for the future and to maintain fixed the norms concerning what are lawful and unlawful behaviours (Luhmann, 1985, Chapter 2; Luhmann, 2004, Chapter 3; Tosini, 2003a; King and Thornhill, 2003).

This 'monopolisation' by law of the function of the stabilisation of expectations depends on a typical phenomenon of modern society: that of functional differentiation, 
i.e., the separation of social functions and their assignment to different social fields, referred to here as functional subsystems. In addition to law, the other most important subsystems of modern society are the economy, science, art, religion, and politics (Luhmann, 1997). In the same way as in the legal system, specific structures in each of these subsystems adopt one social task, performing it autonomously and independently. In short, modern and contemporary society is a social system broken down into various subsets of communication, each of whose specific aims is to carry out its own social function.

Unlike and opposite to pre-modern society, one can say that modern society is oriented toward the future (Luhmann, 1980); which means that every subsystem is continuously forced to modify its own structures (i.e. programmes): statutes and case law within the legal system; theories and technologies, in the case of science, for example. This continuous modification ensures an increasingly efficient performance of each function in accordance with the needs of social development. This possibility of transforming the social structures is, however, only one side of the matter, the positive side. In fact, the idea that, by deciding in the present, the future will offer new forms, for example, of statutes, theories and technologies, does not necessarily mean that they will be exclusively a source of benefits. Owing to a series of accidents, in particular technological ones, modern society has learnt that present decisions addressed at changing social organisations can always be linked to the possibility of injuries, damage, loss, etc. Modern society's constant evolution of its structures to cope with future change is deeply associated with the concept of risk (Beck, 1992; Luhmann, 1993, Chapter 2; Beck et al., 1994; Tosini, 2003b, 2004).

The consequence of such an awareness of negative results linked to human behaviour has been the increasing phenomenon of a specific form of communication addressed to underline possible injuries depending on present decisions or to impute present accidents to past decisions. We shall denominate this kind of communication as risk communication. Risk communication is a broad form of communication, widely diffused throughout everyday life. However, special spheres in contemporary society, which specialise in performing such a form of communication, can be identified. There is no doubt that social movements are the most important example among these spheres. In fact, social movements, in general, are social systems whose operations are continuously oriented to criticising several kinds of decisions-for example, political or economic decisions - over possible or actual damage attributed to them (Halfmann and Japp, 1993; Luhmann, 1995b; Cevolini, 2003; Tosini, 2004). At the same time, there is no doubt that the most alarming are the decisions and accidents that can affect the psycho-physical integrity of individuals and the equilibrium of the natural environment. These particular kinds of risk will be distinguished here as ecological risks and the correspondent communication as ecological communication (Luhmann, 1989; Tosini, 2004).

The law has developed its own specific attitude to the risks of modern society. Strict liability is a form of intervention, whose aim is to limit these risks. However, such an intervention requires openness by the law toward the demands from social movements and other spheres of risk communication. This means that, in order to intervene against risks, the law itself must generate its own internal ecological communication-legal ecological communication. One can find this communication in the gradual updating of rights and correspondent kinds of injury. Indeed, one can observe an increasing attempt to establish 
adequate compensation not only for financial or economic losses, but also for personal losses or non-economic losses (Munkman, 1989; Kemp, 1990; Rogers, 2001).

\section{Modern strict liability}

The openness of the law toward the damage provoked within the ordinary social activities has led to an increasing call for specific measures of intervention. Strict liability could be considered the most revolutionary, in that it challenges some fundamental principles of modern law. According to the American Jurisprudence, 'Under the doctrine of strict liability in tort, the liability is 'strict' in the sense that it is unnecessary to prove the defendant's negligence. The doctrine of strict liability is applicable, although the defendant 'has exercised all possible care in the preparation and sale of the product.' [...]' (American Jurisprudence, 1996, pp. 450-451). This definition shows the contrast between such an instrument and the traditional principle of fault.

In the context of modern society, fault constitutes the cornerstone of the Civil Law. ${ }^{1}$ Fault is also the central tenet of the Anglo-American tort of negligence, which, after the abolition of the old forms of action in the second half of the Nineteenth Century, became the most important element of the law of tort - in particular, during the industrialisation of the US (Franklin and Rabin, 1996, pp. 29-30; Gregory, 1951). At the same time, while R. von Jhering in Europe was arguing that 'No liability [is possible] without fault' (Jhering, 1879), on the other side of the Atlantic Holmes could state that 'The general principle of our law is that loss from accident must lie where it falls, and this principle is not affected by the fact that a human being is the instrument of misfortune' (Holmes, 1881, p. 94), thus confirming the decision to exclude the offset concerning losses not imputable to the violation of specific norms of the law.

The ascent of strict liability is related to the increasing impact of industrialisation upon the bodily integrity of human beings. This is particularly evident in a case that can be considered the first piece of legislation based upon the principle of strict liability: the 1838 Prussian Eigenbahngesetz (Brüggemeier, 1999, p. 81). Under Common Law, the first leading pronouncement of strict liability is usually believed to be that of Ryland v. Fletcher (1868). ${ }^{2}$ Between the end of the Nineteenth Century and the beginning of the Twentieth Century, in Europe as well as in the US there was a strong ideological movement supporting the reform of the law of tort-what Prosser will call the assault upon the citadel of the old principles (Prosser, 1960, 1966). Seilles (1897), Josserand (1897), Demogue, 1918-19), and Ripert (1949), in France (Castronovo, 1991); Coviello (1897), Barassi (1898), and Venezian (1919), in Italy (Castronovo, 1991); Unger (1883), Mataja (1888), Rümelin (1910), Merkel (1913), Esser (1941), and Binding (1965), in Germany (Ogorek, 1975): these were the most important European scholars calling for broader measures of social insurance based upon an extension of the applications of strict liability.

Several American scholars argued in the same vein, by underlining the necessity of taking into account the social implications of the law of torts. Here, the most important sources can be found, for example, in the pragmatism of Ch. Pierce, W. James, Ch. Wright,

\footnotetext{
${ }^{1}$ See, for example, Code Napoléon (1804, art. 1382); Allgemeins Bürgerliches Gesetzbuch (1811, Section 1295); Italian Codice Civile (1865, art. 1151).

${ }^{2}$ L. R. 3 H.L. 330.
} 
N.St.J. Green and Holmes (1897), in the institutional economics of Th. Veblen. J.R. Commons, W. Mitchell and H. Seanger, and in legal realism of H. Lanski, L. Green, J. Llewellyn and B. Cardozo (Hackney, 1995). In general, there is a clear attempt to go beyond the individualistic perspective of past law based upon the principle of fault, with the expectation of promoting a higher level of social justice (Laski, 1916, pp. 111-112). This approach was developed by legal scholars such as James (1938, 1941, 1948), Kessler (1943), and Prosser (1955) (Rabin, 1969; White, 1980; Priest, 1985; Gordley, 2000). To some extent, the same approach has been shared by numerous contemporary theorists, although certain theoretical differences have to be mentioned. In fact, for example, one can distinguish at least between two kinds of criteria supporting strict liability. On the one hand, there are scholars such as Fletcher (1972), Epstein (1973, 1985) and Coleman (1992), whose arguments chiefly adopt moral criteria which try to challenge the principle of fault (Tosini, 2003b; Steele, 2004). On the other hand, recent developments in legal theory have encouraged the use of new criteria such as those of the economic analysis of law, upon which, for example, G. Calabresi has based, to a large extent, his theory of strict liability (Calabresi, 1970; Calabresi and Hirschoff, 1972; Calabresi and Klevorick, 1985; Attanasio, 1988). ${ }^{3}$

In Europe, this new ideological movement faced strong resistance from the conservative orientation of the courts, concerned with the rigid application of the principle of faultmaintained at the heart of the old codes. The alternative was to be found in a long series of special legislations, as it is particularly evident in Germany, where, after the old 1838 Eisenbahngesetz, numerous new statutes were ratified. ${ }^{4}$ These provisions, together with the development of insurance, contributed to the consolidation of the Welfare State- or of what Ewald termed L'Etat providence (1986).

In the US, the situation was different. In this context, an highly important promoters of reform of the law of tort were the courts, due to a synergic relations with the intellectual movement supporting this reform. In this way, judges increasingly abandoned the previous perspective centred upon the analysis of the isolated relationship involving the plaintiff and the defendant alone. Thus, in parallel with the increasing relevance achieved in many legal scholars' mind by the social consequences of law of torts, the courts also experienced an innovative attention paid to the new legal solutions able to promote a higher level of social justice. Following this tendency, specific leading cases paved the way for the triumph of strict liability. In Escola v. Coca Cola Co. Bottling of Fresno (1942), J. Traynor could state:

In my opinion it should now be recognised that a manufacturer incurs an absolute liability when an article that he has placed on the market, knowing that it is to be used without inspection, proves to have a defect that causes injury to human beings. [...]. Even if there is no negligence, however, public policy demands that

\footnotetext{
${ }^{3} \mathrm{Cfr}$. the proposal advanced by Trimarchi (1961). To be precise, the economic analysis of law also provides certain arguments against strict liability: See, for example, Posner (1972, 1973).

${ }^{4}$ Strassenverkhrsgesetz (1908); Luftverkehrsgesetz (1922); Wasserhaushaltsgesetz (1957); Atomgesetz (1958); Arzneimittelgesetz (1976); Haftpflichtgesetz (1978); Bundesberggesetz (1980); Produkthaftungsgesetz (1989); Gentechnikgesetz (1990) and Umwelthaftungsgesetz (1990). See Somma (1995, 1998), Esser (1953), Medicus (1996), Deutsch (1996, pp. 405-472), Baudisch (1998). As promoters of reform of the 1900 German code, see Deutsch and Zweigert (1966), Kötz (1970), Caemmerer (1971), Weitnauer (1971), Deutsch (1976), Will (1980), and Kötz (1981).
} 
responsibility be fixed wherever it will most effectively reduce the hazards to life and health inherent in defective products that reach the market. It is evident that the manufacturer can anticipate some hazards and guard against the recurrence of others, as the public cannot. [...]. Against such a risk there should be general constant protection and the manufacturer is best situated to afford such protection. 5

Such an approach, together with other pronouncements, ${ }^{6}$ constituted the basis for the most important advance in the reform of the law of tort, that is, the 1965 Restatement of the Law (Second): Torts 2d-in particular, the Section 402A ('Special Liability of Seller of Product for Physical Harm to User or Consumer') (The American Law Institute, 1965, pp. 347-348). Between the 1960s and the 1980s, numerous sentences applied such principles systematically. In general, the courts became the most powerful agents in order to compensate for the disadvantages of modern risks, thus characterising a specific American form of Welfare (Courts).

In the circumstances of the application of strict liability, the contrast between the principle of fault and that of strict liability became more and more apparent. So, for example, in the case of Beshada v. Johns-Manville Products Corp. (1982), a manager of a company treating asbestos was considered liable for the damage caused to his employees at a time when nobody knew of the dangerousness of the material. According to the court, "[the] 'state of art' at a given time is partly determined by how much industry invests in safety research. By imposing on manufacturers the costs of failure to discover hazards, we create an incentive for them to invest more actively in safety research. [...]". ${ }^{7}$ In order to ensure compensation to the employees who were injured by asbestos, this decision ignores the statements of law about what was lawful/unlawful at the time of working - namely the legality of the treatment of asbestos. In this sense, strict liability is clearly liability without fault.

\section{Functions and consequences of strict liability}

The attempt through strict liability to compensate for the risks of modern and contemporary society corresponds to a very sophisticated process of 'internalisation' of risk. Following this process, the legal system is attempting to rectify its own decisions about what is lawful/unlawful, if specific damage has emerged; more precisely, such a rectification operates in the form of an imputation of liability to those individuals whose activities are observed as the cause of the damage, even though at the time of the execution of such activities no unlawfulness could be pointed out. Why, one can ask, has the law reached so problematic a condition?

Specific answers can be found in the principles underlying the courts' policy. Product liability - that is, the liability concerning losses and injuries caused by defective productsand medical malpractice liability — namely the civil liability of the medical profession - for example, represent two sub-fields of civil law characterised by a clear discontinuity between two periods of the American law of tort. Prior to the 1960s, the courts, following the fundamental principle of negligence, imputed liability, for example, to a doctor, if his

\footnotetext{
${ }^{5}$ Escola v. Coca Cola Bottling Co. of Fresno, 24 Cal. 2d 453, 150 P. 2d 436 (1944).

${ }^{6}$ For example, Greenman v. Yuba Power Products, Inc., 59 Cal. 2d 57, 377 P. 2d 897, 27 Cal. Rptr. 697 (1963).

${ }^{7}$ Beshada v. Johns-Manville Products Corp., 90 N.J. 191, 447 A. 2d 539 (1982).
} 
moral culpability for breaching standards of community practice could be demonstrated. Since the late 1960s, by contrast, the court's policy has changed dramatically (Priest, 1990, p. 210). In other words, in the case of medical malpractice, as well as in the case of product liability, the courts' method for the evaluation of individual responsibility refers to the amount of contribution by a specific party-which is assumed a priori to be that of the doctor, in the case of medical malpractice, or that of the manufacturer, in the case of product liability - to the occurrence of the harm, the clear demarcation between moral and non-moral dimensions of liability thus losing any relevance.

Such a revolution in the direction of modern adjudication has been based upon a specific conception of the law's role, namely on the principle according to which the fundamental purpose of intervention by courts is to maximise social welfare (Priest, 1990, p. 215). Indeed, the result which the theories and applications of liability without fault expect to achieve is a higher level of social justice: in other words, as equal a distribution of the cost of accidents as possible.

Given such a purpose, in the arguments adopted by the courts two different and alternative strategies can be identified. If the damage could have been practicably prevented, the decision will consist - assuming the first strategy - of identifying as liable the party-involved in a specific accident - considered as the source of the damage itself and, at the same time, as the one in the relatively better position to prevent it - even though no negligence can be demonstrated. Following such a strategy, the courts aim to promote a deterrent effect (accident avoidance), that is, to induce the charged party to more intense investment in a product's safety. ${ }^{8}$

The second and alternative strategy will be adopted when, according to the court's analysis, no evidence exists to show that any party involved could have prevented the damage. Nevertheless, some courts' statements have no hesitation in contending that, in these cases, liability should be placed on the party in the better condition to spread the costs of the damage (risk spreading). In such circumstances, the courts' intervention refers to the possibility of transferring the cost of compensation onto both the insurance premiums paid by the charged party-for example, companies involved in certain accidents - and the price of the products manufactured by the companies themselves. The courts' premise is that the mechanisms of both the premium and the price offer the opportunity to spread and homogeneously divide the cost of injuries over wide communities of individuals - the community of the insured (and charged) party, on the one hand, and the community of consumers, on the other (Priest, 1985, 1989).

In sum, according to these strategies courts have been assuming a clear intent to compensate for certain types of damage, evaluated as effectively preventable and conveniently amortisable by a specific party (manufacturer or physician, for example), even though such an intent could require that the responsibility should be imputed to a party

\footnotetext{
${ }^{8}$ In this regard, the criterion advanced by Calabresi and Hirschoff is the following. They argue that 'liability would be placed on the party initially free of responsibility only if the decider found the benefits of avoidance (i.e., not incurring the cost of the accident) to be greater than the costs of such avoidance to the party. The strict liability test we suggest does not require that a governmental institution make such cost-benefit analysis. It requires of such institution only a decision as to which of the parties to the accident is in the best position to make the cost-benefit analysis between accident costs and accident avoidance costs and to act on that decision once it is made. The question for the court reduces to a search for the cheapest cost avoider' (Calabresi and Hirschoff, 1972, p. 1060).
} 
having no fault. This is the specificity of strict liability. In other words, the need to achieve compensation for as broad a variety of losses as possible - in order to protect more effectively the integrity of individuals facing the menaces of modern society - is bound, in some cases, to the necessity of sacrificing past decisions by the law confirming the lawfulness of certain activities, whose agents, according to the recent decisions, are charged to pay for the damage.

The analysis presented so far is useful in order to understand the policy supported by the courts and several legal scholars, but offers neither a sufficient clarification of the social dynamic underlying the application of strict liability, nor any account of the function to be performed by this dynamic. In order to satisfy such requirements, it is useful to develop our analysis in the context of the theory of systems, as follows.

In the first instance, it is necessary to keep in mind the specificity of modern society, namely the differentiation of a plurality of subsystems (the economy, medicine, and the law itself, for example), each of which is oriented to perform its own function. At the same time, it has become increasingly evident that dangerous consequences for the integrity of human beings and the natural environment are associated with the continuous performance of such functions, including those cases in which such a performance, according to specific past statutes and past regulations, was lawful. As we have shown, a corresponding observation of these risks has been generated by a particular communication, named ecological communication.

At this point, one could expect that societies facing similar consequences might conclude that they need to ban the dangerous activities causing the harm. But they do not. In fact, despite the persistent experience of defective (and lawfully) manufactured products, for example, the decision to ban certain kinds of mechanised production would be tantamount to conflict with the performance of the economic system; in other words, it would correspond to interference with the functional rationality of the economic subsystem.

Nevertheless, due to the attention paid by ecological communication to the risk to human beings and the natural environment, there are increasing demands for legal intervention to protect both. Such demands call for measures to promote compatibility between technological innovations and their application to several social activities such as economic and medical ones, on the one hand, and the requirement for their safety in order to ensure the integrity of human beings and the environment, on the other. Only by focusing on this requirement of compatibility - as embedded in the above mentioned specific conditions of a (modern) functionally differentiated societycan strict liability be adequately understood. More precisely, according to our hypothesis, strict liability is a sophisticated social mechanism concerned with the need to control many (useful) social activities (lawfully) causing damage, without the possibility of banning them.

In such a complicated situation, the old instrument of fault can offer no help, in that the problem to be dealt with concerns damage determined by lawful activities. Insisting on adopting the principle of fault would correspond to indifference toward the increasing amount of conflicts triggered off by ecological communication such as that of social movements - consumer watchdogs, for example. To be sure, this communication and the conflicts associated with it contribute, by their own performance, to a very important function, namely what we name "alarming thematisation". This means that, through social movements, society can become aware of the existence of specific "facts", insofar as, thanks to the social movement, they are turned into themes of communication. At the same 
time, in order to focus the attention of politics and the law upon them, these themes have to be presented in the form of a specific, communicative frame, the alarming and conflicting one, representing them as a problem; this is exactly the further contribution accomplished by social movements, in particular, and ecological communication, in general. Finally, the development of ecological and conflicting communication effectively provides the opportunity of promoting people's participation in social, verbal interactions and social, verbal disputes, rather than in violent struggle, thus ensuring the protection of human integrity and, consequently, the continuation of the system of communication itself.

Thanks to ecological communication-for example, in the form of the social movements - modern society has been introduced to two fundamental processes, namely the detection of the (ecological) tensions between certain, dangerous social activities and the human beings injured by them, on the one hand, and the promotion of non-violent behaviour by individuals protesting against the negative consequences of these activities, on the other. In other words, without such detection, the result would be to ignore such dangers and, in so doing, to run the risk of destroying not only bodily and psychological integrity, but also society itself-because, obviously, no communication can exist without human beings; at the same time, an inability to channel the protest into the form of a verbal, conflicting communication would cause violence and, consequently, another source of destruction of human beings and society.

However, once the ecological tensions have been turned into communication, what society then has to do is to provide a more adequate mechanism addressed to managing the conflicts associated with this communication, on the one hand, and to establish new regulations for preventing the accidents which injure human beings, on the other. Only the law and, more precisely, only the law of tort based upon the principle of strict liability, has contributed to both tasks. The manner by which this has occurred is the next point to be addressed.

With regard to the conflicts and alarms referring to negative consequences, the fundamental first task of the law consists in opening its own communication to them. This means that the law has to promote the inclusion of protest into its own procedures. Such an inclusion would ensure a higher level of regulation of conflict than would be the case for a diffuse protest such as that of the social movements, in which there is always the possibility of some episode of violence. ${ }^{9}$ By contrast, the advantage of legal communication is to provide for specific procedures such as the trials, which guarantee (in principle) a symmetric relationship between the parties (for example, manufacturer and consumer) that is, an equal opportunity for the protection of their own rights - and are thus able to induce people to refer to these procedures, rather than carrying on the conflict outside them. The likelihood that this inclusive and regulated process will prove more effective is fostered by the possible satisfaction of a higher expectation of protection and compensation. This is exactly what happens in the event of the adoption of the principle of strict liability, once one compares it with that of fault. Strict liability promises new opportunities for

\footnotetext{
${ }^{9}$ This point has to be stressed. It refers to the sophisticated relations between ecological tensions, verbal communication and violence. What my argument means is that protest is, to some extent, a contribution to promoting people's participation in verbal disputes. But, as explained, it is always possible that some episode of violence can result from the process of the protest itself. Thus, the following part of the argument underlines the necessity - in order to improve what will be identified as the immunisation of social systems - of embedding the conflict into the legal procedures, which increase the probability of preventing violence.
} 
damages against the risks of contemporary technologies and, in so doing, stimulates it is true a greater probability of conflicts, but these are legal conflicts, that is, absolutely nonviolent disputes. Maintaining the principle of fault alone would be tantamount to displaying indifference toward social tensions and, consequently, to exposing them to the "infection" of possible violent behaviours. Moreover, thanks to compensation for the new forms of loss such as personal losses, the law can also facilitate the (however provisional) resolutions of certain episodes of conflict, insofar as, through the allocation of damages, the legal system is able to meet the need for the protection called for by the ecological communication's protest.

Finally, as we have shown, the further purpose of the court's policy has been that of imputing responsibility to the party considered capable of preventing (by investing in safety) the losses. This corresponds to a peculiarity of the legal system's rationality, which, in so doing, contributes to limiting of the risk associated with modern, mechanised activities (in the field of the economy or medicine, for example). In other words, thanks to such a legal intervention, society has the possibility to improve the protection of its own environment (human beings and the natural environment), and at the same time to preserve of its own integrity-consisting of the reproduction of communication - insofar as, again, no communication system would be possible without its environment.

Summarising our observations, one can distinguish four processes, each of which can be described as being part of a more comprehensive mechanism of the immunisation of society $^{10}$ with respect to the collateral consequences associated with ecological risks. (1) The first process (A) consists of the (alarming) emergence at the level of communication of (ecological) tensions between risky social activities and human beings, in order to promote adequate measures to protect the integrity of the latter against the former. As we have seen, the fundamental social context contributing to such an emergence is ecological communication, such as that of protest by social movements. (2) At the same time, this context also generates to some extent the second process (B), namely the channelling of ecological tensions into verbal communication - in the form of the participation by individuals in collective protest against dangerous activities - thus obstructing the use of violent behaviour, which would be a threat to social order. (3) In reality, the most effective context to control such a threat is provided by the procedures of the legal system. More precisely, the law leads to the third process $(\mathrm{C})$ which we have analysed above, that is to the regulation and (however provisional) resolution of the conflicts. As we have documented, compared with the principle of fault, strict liability is particularly effective in promoting such regulation and resolution, insofar as it offers the possibility of a higher satisfaction of the need for compensation for the new losses. (4) Finally, the law, particularly through strict liability, performs the fourth process (D), namely the prevention of events injuring human beings, by elaborating criteria of imputation of responsibility addressed to improve deterrence against risky decisions, thus meeting the claims coming from the context of the ecological communication. In the following graph we try to summarise the logic of social immunisation through ecological communication and legal procedures.

\footnotetext{
${ }^{10}$ For the analysis of the legal system as immune system of society, see Luhmann (1995, Chapter 9; 2004, Chapter 3), Tosini (2003a, 2004).
} 
SOCIAL IMMUNISATION THROUGH ECOLOGICALCOMMUNICATION \& LEGAL PROCEDURES

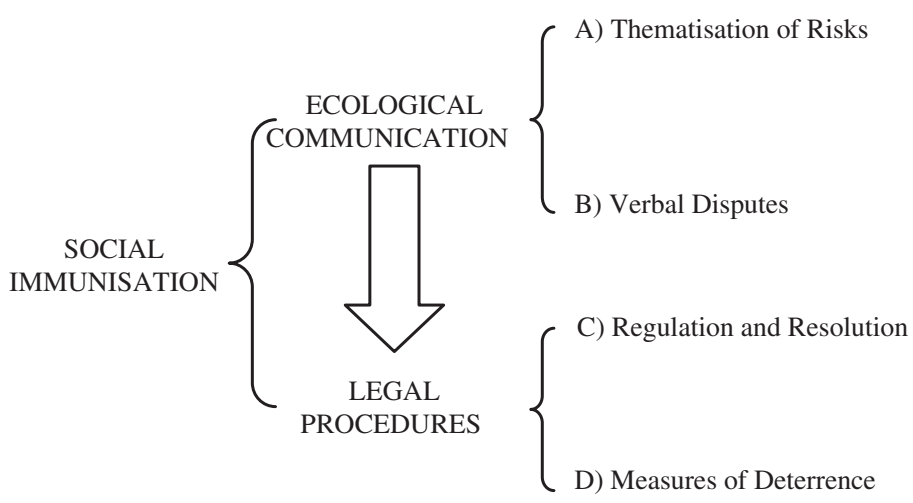

Despite the noble intent of preventing accidents and achieving a higher level of social justice through the application of strict liability, specific data indicate its failure. In particular, the widely questionable courts' assumption that one specific party-for example, the doctor or manufacturer - can be assumed to be the one able to prevent the damage - and, therefore, considered as liable (first strategy) - has led to an increasing interference in certain social activities such as industrial and medical activities. These have been affected by a considerable increase in the number and size of claims since the late 1960s, even though it has been proved that since then the accident and injury rates related to such activities have declined and their safety has been improved overall. As a dramatic result of this interference, empirical investigations have documented significant changes in the management of those activities: for instance, the trend toward the restriction of certain products, the interruption of product research or the refusal to perform certain types of services (Priest, 1987, 1991; McGuire, 1988; Spier, 1998).

Parallel to this impact of product liability, an additional effect can be observed, which indicates the courts' failure to perform a higher level of social justice. In this regard, if one focuses on the intent of the second strategy of the courts' policy, then one can argue that the aim of spreading and sharing equitably the cost of injuries among the communities of the insured (and charged) parties, on the one hand, and consumers, on the other, is far from being achieved. In particular, the criterion - promoted by the courts - of the equal allocation of the cost of injuries, - through market processes - onto the price of every product unit and every single consumer ignores the fact that the calculation of insurance premiums, affecting the price of products, is based on relatively high levels of income quantifying the amount of damages; which means that the equal spread of price rises undercharges high-income consumers and overcharges low-income consumers (Priest, 1990, p. 226).

Such 'collateral consequences' of the application of strict liability constitute without doubt a very serious problem in the immunisation of the communication system of society. In general, two kinds of consequences can be distinguished. The first concerns the structures of the law. On the one hand, the necessity of protecting human beings injured by new technology requires the adoption of new criteria for the imputation of responsibility 
such as strict liability. On the other hand, as seen for example in Beshada v. Johns-Manville Products Corp (1982), these criteria create a serious contradiction within the legal system, in that they attribute the responsibility to someone (the manufacturer, for example) whose activity was lawful according to the previous decisions of the legal system itself. As a result, the defendant is forced to compensate for something unlawful (a specific loss) associated with something lawful (his or her own behaviour). In other words, the attempt by the law to manage the dangers of modern society corresponds to a highly radical internalisation of risk, so that the law is compelled to very frequent and rapid corrections of its decisions, thus provoking, in some cases, apparent self-destabilisation of the legal structures.

At the same time, a second kind of consequences can be underlined, associated with the external implications of risk management through strict liability. As documented, for some kinds of profession, such as that of physician, the application of strict liability becomes an evident threat, thus inducing many professionals to change or modify their activities. Moreover, at the level of economic impact, many critics underline the failure of strict liability to achieve a higher standard of social justice. Generally speaking, both phenomena show a collision between the legal system and the other subsystems, such as the medical and economic system.

\section{Concluding remarks}

Both kinds of consequences examined (the internal and the external) can be understood in the context of an apparent emergence (at the level of the law's decisions) of a dramatic tensions between the functional subsystems of society, such as the economic system, and the need to protect human beings. The role played by the law in this situation is that of elaborating new solutions in order to improve the compatibility between the performance of the subsystems and the integrity of human beings. One of the most important solutions is the principle of strict liability (liability without fault). Nevertheless, by adopting this form of management of risk, law could provoke the destabilisation of legal structures and a collision with the specific requirements of other functional subsystems, such as the economic system. As a result, the need to limit the risks of modern technology promotes no automatic, homeostatic evolution of the communication system of society. Rather, the expectation of an extremely problematic co-existence of new and dangerous activities and new rights of protection produces an overload within the legal decisions-making process, which, in turn, affects the stability of legal structures and the interactions between the law and the other subsystems. In this way, the specific conditions of contemporary society requires special legal interventions (such as that of strict liability) which conflict with the traditional functions of the law itself.

\section{Acknowledgement}

The author would like to thank professor Michael King for his comments on the earlier version of this article.

\section{References}

American Jurisprudence, 1996. A Modern Comprehensive Text Statement of American Law. State and Federal, vol. 63: Products Liability. Lawyers' Cooperative Publishing, New York. 
American Law Institute (Ed.), 1965. Restatement of the Law (Second): Torts 2d, vol. 2. American Law Institute Publishers, St. Paul, MN.

Attanasio, J.B., 1988. The principle of aggregate autonomy and the calabresian approach to product liability. Virginia Law Review 74, 677-750.

Barassi, L., 1898. Contributo alla teoria del responsabilità per fatto non proprio, Torino.

Baudisch, B., 1998. Die gesetzgeberischen Haftungsgründe der Gefährdungshaftung. Shaker Verlag, Aachen.

Beck, U., 1992. Risk Society. Sage, London.

Beck, U., Giddens, A., Lash, S., 1994. Reflexive Modernization. Polity Press, Cambridge, UK.

Binding, K., 1965. Die Normen und ihre Übertretung. Scientia Verlag Aalen, Leipzig.

Brüggemeier, G., 1999. Prinzipien des Haftungsrechts. Nomos Verlagsgesellschaft, Baden-Baden.

Caemmerer, E.von, 1971. Reform der Gefährdungshaftung. De Gruyter, Berlin, New York.

Calabresi, G., 1970. The Cost of Accidents. Yale University Press, New Haven.

Calabresi, G., Hirschoff, J.T., 1972. Toward a Test for Strict Liability in Torts. The Yale Law Journal 81, $1055-1085$.

Calabresi, G., Klevorick, AK., 1985. Four tests for strict liability in Torts. The Journal of Legal Studies 14, 585-627.

Castronovo, C., 1991. Responsabilità oggettiva II-Diritto comparato e straniero. Enciclopedia Giuridica Treccani 27.

Cevolini, A., 2003. Movimenti sociali. In: Addario, N. (Ed.), Teoria dei sistemi sociali e modernità. Carocci, Roma, pp. 275-284.

Coleman, J.L., 1992. Risks and Wrongs. Cambridge University Press, Cambridge, UK.

Coviello, N., 1897. La responsabilità senza colpa. Rivista italiana per le scienze giuridiche, vol. 23.

Demogue, R., 1918-19. Fault, risk and apportionment of loss in responsibility. Illinois Law Review 13.

Deutsch, E., 1976. Haftungsrecht. Carl Heymanns Verlag KG, Berlin, München.

Deutsch, E., 1996. Allgemein Haftungsrecht. Carl Heymanns Verlag KG, Berlin, München.

Deutsch, E., Zweigert, K., 1966. Die Haftung für gefährliche Anlagen in den EWG-Länder sowie in England und die Vereinigten Staaten. Mohr, Tübingen.

Epstein, R., 1973. A theory of strict liability. The Journal of Legal Studies 2, 151.

Epstein, R., 1985. Product liability as an insurance market. The Journal of Legal Studies 14, 645.

Esser, J., 1941. Grundlagen und Entwicklung der Gefährdungshaftung. C.H. Beck'Sche Verlagsbuschhandlung, München, Berlin.

Esser, J., 1953. Die Zweispurigkeit unseres Haftpflichtrechts. Juristenzeitung 8, 129-134.

Ewald, F., 1986. L'Etat providence. Grasset, Paris.

Fletcher, G., 1972. Fairness and utility in Tort theory. Harvard Law Review 85, 537.

Franklin, M.A., Rabin, R.L., 1996. Tort Law and Alternatives: Cases and Materials. University Casebook Series. The Foundation Press, Inc., Westbury, New York.

Gordley, J., 2000. The common law in the twentieth century: some unfinished business. California Law Review 88, 1815.

Gregory, Ch.O., 1951. Trespass to negligence to absolute liability. Virginia Law Review 37, 359-397.

Hackney Jr., J.R., 1995. The intellectual origins of American strict products liability: a case study in American pragmatic instrumentalism. The American Journal of Legal History 39, 443-509.

Halfmann, J., Japp, K., 1993. Modern social movements as active risk observers: a system-theorethical approach to collective action. Social Science Information 32 (3), 427-446.

Holmes, O.W., 1881. The Common Law, Boston.

James, F., 1938. Last clear chance: a transitional doctrine. The Yale Law Journal 47, 704-723.

James, F., 1941. Contribution among joint Tort Feasor: a pragmatic criticism. Harvard Law Review 54, $1156-1169$.

James, F., 1948. Accident liability reconsidered: the impact of liability insurance. The Yale Law Journal $57,549$.

Jhering, R. von, 1879. Das Schuldmoment im römischen Privatrecht. In: Breitkopf und Hartel (Eds.), Id., Vermischte Schriften. Leipzig.

Josserand, L., 1897. De la responsabilité du fait des choses inanimées. Arthur Rousseau Éditeur, Paris.

Kemp, D., 1990. Damages for Personal Injury and Death. Longman, London.

Kessler, F., 1943. Contracts of adhesion: some thoughts about freedom of contract. Colorado Law Review 43, 629.

King, M., Thornhill, Ch., 2003. Niklas Luhmann's Theory of Law and Politics. Palgrave MacMillan, New York. 
Kötz, H., 1970. Haftung für besondere Gefahr-Generalklausel für die Gefährdungshaftung. Archiv für die zivilistische Praxis 170.

Kötz, H., 1981. Gefährdungshaftung. Empfiehlt sich eine Vereinheitlichung und Zusammenfassung der gesetzlichen Vorschriften über die Gefährdungshaftung in BGB und erscheint es erforderlich, das Recht der Gefährdungshaftung weiterzuentwickeln? In: Bundesminister der Justi (Ed.), Gutachten und Vorschläge zur Überarbeitung des Schuldrechts, vol. II. Bundesanzeiger Verlages MbH, Köln.

Laski, H.J., 1916. The basis of vicarious liability. The Yale Law Journal 26, 105-135.

Luhmann, N., 1980. Gesellschaftsstruktur und Semantik. Suhrkamp, Frankfurt/M.

Luhmann, N., 1985. A Sociological Theory of Law. Routledge \& Kegan Paul, London.

Luhmann, N., 1989. Ecological Communication. Polity Press, Cambridge, UK.

Luhmann, N., 1993. Risk: A Sociological Theory. De Gruyter, Berlin.

Luhmann, N., 1995a. Social Systems. Stanford University Press, Stanford, CA.

Luhmann, N., 1995b. Protest. Suhrkamp, Frankfurt/M.

Luhmann, N., 1997. Die Gesellscahft der Gesellschaft. Suhrkamp, Frankfurt/M.

Luhmann, N., 2004. Law as a Social System. Oxford University Press, Oxford.

Mataja, V., 1888. Das Recht des Schadenersatzes vom Standpunkte der Nationalökonomie. Verlag Von Duncker \& Humblot, Leipzig.

McGuire, E.P., 1988. The Impact of Product Liability. Conference Board, New York.

Medicus, D., 1996. Gefärdungshaftung im Zivilrecht. Juristische Ausbilding 11, 561-566.

Merkel, A., 1913. Juristische Enzyclopädie. Guttentag Verlagsbuchhanlung, Berlin.

Munkman, J., 1989. Damages for Personal Injuries and Death. Butterworths, London.

Ogorek, R., 1975. Untersuchungen zur Entwicklung der Gefährdungshaftung im 19. Jahrhundert. Böhlan-Verlag, Köln, Wien.

Posner, R.A., 1972. A theory of negligence. The Journal of Legal Studies 1, 29.

Posner, R.A., 1973. Strict liability: a comment. The Journal of Legal Studies 2, 205.

Priest, G.L., 1985. The invention of enterprise liability: a critical history of intellectual foundation of modern Tort law. The Journal of Legal Studies 14, 461-527.

Priest, G.L., 1987. The current insurance crisis and modern Tort law. The Yale Law Journal 96, 1521-1590.

Priest, G.L., 1989. Strict products liability: the original Intent. Cardozo Law Review 10, 2301-2327.

Priest, G.L., 1990. The new legal structure of risk control. Daedalus 119, 207-227.

Priest, G.L., 1991. The modern expansion of Tort liability: its sources, its effects, and its reform. The Journal of Economic Perspectives 5, 31-51.

Prosser, W.L., 1955. Handbook of the Law of Torts. West Publishing Co, St. Paul, MN.

Prosser, W.L., 1960. The assault upon the citadel (strict liability to the consumer). Yale Law Journal 69, 1099-1149.

Prosser, W.L., 1966. The fall of the citadel (strict liability to the consumer. Minnesota Law Review 50, 791.

Rabin, R.L., 1969. Some thoughts on Tort law from a sociopolitical perspective. Wisconsin Law Review 9, $51-81$.

Ripert, G., 1949. La règle morale dans les obligations civiles. Librairie Générale de Droit et de Jurisprudence, Paris.

Rogers, H.W.V. (Ed.), 2001. Damages for Non-Pecuniary Loss in a Comparative Perspective. Springer, Wien, New York.

Rümelin, M., 1910. Schadensersatz ohne Verschulden. Mohr, Tübingen.

Seilles, R., 1897. Les accidents de travail et la responsabilité civile. Essai d'une théorie objective de la responsabilité delictuelle. Arthur Rousseau Éditeur, Paris.

Somma, A., 1995. Le tecniche di imputazione del danno extracontrattuale tra codice civile e legislazione speciale: l'esercizio di attività pericolose nel diritto tedesco. Rivista del diritto commerciale e del diritto generale delle obbligazioni 1-2/3-4, 277-297.

Somma, A., 1998. Le fonti di notevole pericolo nelle esperienze italiana e tedesca. In: Cabella Pisu, L., Nanni, L. (Eds.), Clausole e principi generali nell'argomentazione giuridica degli anni novanta. Cedam, Bologna.

Spier, J. (Ed.), 1998. The Limits of Expanding Liability. Kluwer Law International, London, Boston.

Steele, J., 2004. Risks and Legal Theory. Hart Publishing, Oxford.

Tosini, D., 2003a. Il diritto. In: Addario, N. (Ed.), Teoria dei sistemi sociali e modernità. Carocci, Roma, pp. 215-230.

Tosini, D., 2003b. Contingenza e extragiuridicità del diritto: problemi giuridici del potere costituente e della responsabilità oggettiva. Sociologia del diritto $30,73-98$. 
Tosini, D., 2004. Un concetto di movimento sociale: contributi dalla teoria dei sistemi sociali. Studi di sociologia 42, 241-261.

Trimarchi, P., 1961. Rischio e responsabilità oggettiva. Giuffrè, Milano.

Unger, J., 1883. Handeln auf eigene und Handeln auf fremde Gefahr, Jena

Venezian, G., 1919. Danno e risarcimento fuori dei contratti. In: Idem, Opere giuridiche di Giacomo Venezian, vol. I. Studi sulle obbligazioni. Athenaeum, Roma.

Weitnauer, H., 1971. Haftung für gefährliche Anlagen. In: Carstens, B. (Ed.), Angleichung des Rechts der Wirtschaft in Europa. Köln.

White, E.G., 1980. Tort Law in America. An Intellectual History. Oxford University Press, Oxford.

Will, M., 1980. Quellen erhöhter Gefahr. Rechtsvergleichende Untersuchungen zur Weiterentwicklung der deutschen Gefährdungshaftung durch richterliche Analogie oder durch Generalklausel. C.H. Beck'sche Verlagsbuchhandlung, München. 